
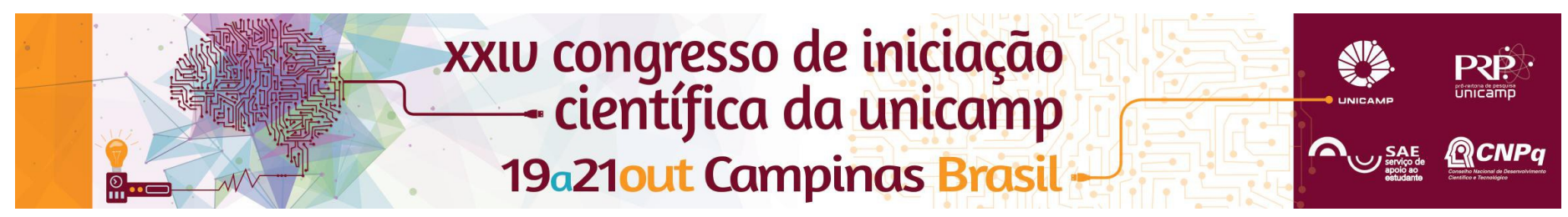

\title{
A POLÍTICA DE HABITAÇÃO E O DESENVOLVIMENTO CAPITALISTA NO BRASIL: O BANCO NACIONAL DA HABITAÇÃO (1964 - 1986)
}

\section{Por Gustavo Delanhese Ramos Tinoco, Orientação: Prof $^{\mathrm{a}}$ Dr$^{\mathrm{a}}$ Milena Fernandes de Oliveira}

\begin{abstract}
Resumo
Esse trabalho busca abordar o papel da Política Habitacional empreendida pelo Banco Nacional da Habitação, dentro do quadro específico do desenvolvimento capitalista brasileiro marcado por fortes heterogeneidades econômicas e sociais exacerbadas no período militar.
\end{abstract}

\section{Palavras-chave: \\ Habitação, Regime Militar, BNH}

\section{Introdução}

A questão habitacional no Brasil possui momentos marcantes que não podem ser entendidos dissociados do quadro histórico os quais estavam inseridos. É nesta linha de pensamento que tentaremos abordar a motivação, estruturação e sentido do Banco Nacional da Habitação, escolhido como ator principal deste trabalho por ser o órgão normativo e regulatório central da Política Nacional de Habitação empreendido pelo governo militar de 1964 até sua extinção, em 1986. A história do Banco, como não poderia deixar de ser, está intimamente ligada ao percuso social e político do próprio regime de então, se desdobrando em consequências que podem ser sentidas ainda hoje no espaço urbano e econômico brasileiro.

\section{Resultados e Discussão}

Diante à crise habitacional e econômica vivida no início dos anos 1960 o governo militar logo se pôs à frente para recuperação do setor, tendo em mente a importância da construção civil como catalizador de mão de obra e mantenedor de nível de renda. Na época, o déficit habitacional já atingia 8 milhões de unidades; a questão deveria ser enfrentada, diante 0 caráter tecnicista do governo, pela ótica creditícia e financeira.

Assim, em 21 de agosto de 1964, por meio da Lei $n^{\circ} 4.380$, nasce o Banco Nacional da Habitação $(\mathrm{BNH})$, financiado pelo Sistema Financeiro de Habitação (SFH). Este, por sua vez, baseava-se em três linhas fundamentais de captação de recursos: (i) Letras Imobiliárias; (ii) cadernetas de poupança pelo SBPE (Sistema Brasileiro de Poupança e Empréstimo); e (iii) o FGTS (Fundo de Garantia por Tempo de Serviço), criado em 1966. Assim, o BNH se torna o segundo maior banco do país, com forte poder na determinação do nível econômico e tendo no SFH um mecanismo de política monetária dentro do quadro macroeconômico.

Há uma complexa relação entre o setor público, provedor dos recursos, e o privado, executor dos empreendimentos habitacionais, prevalecendo uma constante preocupação com o funding perante os retornos exigidos dos agentes envolvidos. A causa imediata dessa lógica é a restrição na oferta de crédito aos grupos que poderiam arcar financeiramente com suas obrigações, excluindo as camadas mais baixas e necessitadas desse tipo de financiamento; além disso a prioridade em executar o maior número de empreendimentos habitacionais com os menores custos penalizava a qualidade arquitetônica e urbanística dessas unidades.

O BNH se estruturou num sistema de captação intimamente vinculado à conjuntura econômica que se encontrava, ou seja, os recursos seriam tão maiores quanto maior for o crescimento econômico, como vice versa. Essa é uma das grandes vulnerabilidades do $\mathrm{SFH}$, que ficava à mercê das flutuações macroeconômicas que poderiam incorrer em aumento da inadimplência e comprometendo o equilíbrio atuarial do sistema, fato que foi sentido com os choques externos de 1979 e o aprofundamento da crise econômica brasileira. Nesse contexto a ruina do BNH é inevitável, corroendo seus recursos, sua credibilidade associada ao regime militar em colapso e sua sustentação como instituição, levando ao seu fim oficial em 1986.

\section{Conclusão}

Apesar das intenções iniciais, o BNH acabou seguindo caminhos que $\mathrm{O}$ distanciaram de seus fundamentos. Seu caso não é diferente de outras políticas e planos na história do Brasil. Mostra-se, portanto, o peso fundamental da conformação estrutural da sociedade na eficácia de certas políticas e ações do Estado. Além disso, é necessário problematizar os rumos das políticas públicas dentro do quadro político vigente para compreender os verdadeiros interesses por trás de sua existência

AZEVEDO, Sérgio de; ANDRADE, Luís Aureliano. Habitação e poder. Rio de Janeiro: Zahar, 1982

KOWARICK, Lúcio (1979). A espoliação urbana. $2^{\circ}$ edição. Rio de Janeiro: Paz e Terra, 1993.

ROYER, L. de O. Financeirização da Política Habitacional: Limites e Perspectivas. Tese (doutorado) - USP/Faculdade de Arquitetura e Urbanismo, Programa de Pós-Graduação em Arquitetura e Urbanismo, Área de Concentração Habitat. São Paulo, 2009.

SANTOS, Cláudio H. M. Políticas Federais de Habitação no Brasil: 1964/1998. IPEA, Brasília - Julho, 1999. 